\title{
Tahfiz Online: Sarana Menghafal Alquran Secara Online
}

\author{
Bobi Erno Rusadi*1 \\ UIN Syarif Hidayatullah Jakarta*1 \\ *1email: bobi.erno@uinjkt.ac.id
}

\begin{abstract}
The development of technology that continues to grow makes it easier for everyone to learn. Likewise with learning the Quran especially memorizing the Quran. Busyness experienced is not a reason not to memorize the Qura. Various online tools and applications can be used to memorize the Quran, one of which is the 'tahfiz online'program. 'Tahfiz Online' is one of the means by which someone memorizes the Quran online by using whatsapp media. This study aims to describe the process of learning memorizing Quran which is carried out by the tahfiz online program which starts from the process of recruiting new students, the learning process, and evaluating the learning which is carried out by the Tahfiz Online program. The research method used is qualitative research with data collection methods of observation and interviews. The results of this study describe that new student recruitment activities carried out by the online tahfiz program are carried out with Alquran reading tests conducted by students by sending voice notes to the teacher (musyrif). Furthermore, in tahfiz learning activities, each student carries out two activities namely ziyadah (adding new memorize) and murajaah (repetition). Ziyadah activities are carried out every Monday to Friday by sending voice notes in the group that will be corrected by each musyrif. Whereas the deliberate activities carried out on Saturdays and Sundays are carried out in pairs. Evaluation of learning are carried out every week with aspects of assessment including daily memorization values, activeness in groups, etiquette, and ending with a final exam with the term IMTAK (Imtihan Akbar).
\end{abstract}

Artikel Info

Received:

Keyword: Learning, Tahfiz Online, Whatsapp.

05 April 2020

Revised:

23 April 2020

Accepted:

26 May 2020

Published:

04 June 2020

\section{Abstrak}

Perkembangan teknologi yang terus berkembang memudahkan setiap orang untuk belajar. Begitu juga dengan belajar Alquran terlebih menghafal Alquran. Kesibukan yang dialami tidak menjadi alasan untuk tidak menghafal Alquran. Berbagai sarana dan aplikasi online dapatt 
dimanfaatkan untuk menghafal Alquran, salah satunya program tahfiz online. Tahfiz online merupakan salah satu sarana seseorang untuk menghafal Alquran secara online dengan menggnakan media whatsapp. Penelitian ini bertujuan untuk mendeskripsikan proses pembelajaran tahfiz Alquran yang dilaksanakan oleh program tahfiz online yang diawali dari proses perekrutan santri baru, proses pembelajaran, serta evaluasi pembelajaran tahfiz yang dilaksanakan oleh program tahfiz online. Metode penelitian yang digunakan yaitu penelitian kualitatif dengan metode pengumpulan data yaitu observasi dan wawancara. Hasil dari penelitian ini mendeskripsikan bahwa kegiatan rekrutmen santri baru yang dilaksanakan oleh program tahfiz online dilakukan dengan tes membaca Alquran yang dilakukan santri dengan mengirimkan pesan suara (voice note) kepada guru (musyrif). Selanjutnya, pada kegiatan pembelajaran tahfiz, setiap santri melaksanakan dua kegiatan yaitu ziyadah (menambah hafalan baru) dan murajaah (mengulang hafalan). Kegiatan ziyadah dilaksanakan setiap Senin sampai Jumat mengirimkan pesan suara (voice note) di dalam grup yang akan dikoreksi oleh setiap musyrif. Sedangkan kegiatan murajaah dilaksanakan Sabtu dan Minggu yang dilakukan secara berpasangan. Kegiatan evaluasi pembelajaran dilaksanakan tiap pekan dengan aspek penilaian di antaranya nilai hafalan harian, keaktifan di dalam grup, adab, dan diakhiri dengan ujian akhir dengan istilah IMTAK (Imtihan Akbar).

Keyword: Learning, Tahfiz, Online, Whatsapp.

\section{A. Pendahuluan}

Perkembangan pada berbagai bidang terus melaju pesat. Salah satunya pada bidang teknologi. Begitu pesatnya perkembangan teknologi membuat seorang individu dengan individu tidak lagi berbatas. Seseorang yang berada di Indonesia sangat mudah untuk berinteraksi dan berkomunikasi dengan seseorang pada belahan dunia yang lain. Kemajuan pada bidang teknologi ini, memberikan kemudahan bagi setiap individu untuk mengakses segala informasi dari berbagai sumber. Hal ini juga memberikan dampak positif pada sektor pendidikan. Pada sektor pendidikan, perkembangan teknologi komunikasi ini memberikan 
kemudahan bagi pendidik atau peserta didik untuk mengakses serta mendapatkan informasi dari berbagai sumber melalui internet. Bahkan pendidik dan peserta didik yang berada di pedesaan juga mampu mengakses berbagai informasi yang berasal dari luar negeri hanya melalui 'satu sentuhan'.

Pemanfaatan teknologi dalam dunia pendidikan khususnya dalam sistem pembelajaran telah mengubah sistem pembelajaran pola konvensional atau pola tradisional menjadi pola modern yang bermedia Teknologi Informasi dan Komunikasi atau Information and Communication Technology (ICT). Salah satu di antaranya adalah media komputer dengan internet-nya yang pada akhirnya memunculkan e-learning. Pada pola pembelajaran bermedia ICT ini, pembelajar dapat memilih materi pembelajaran berdasarkan minatnya sendiri, sehingga belajar menjadi menyenangkan, tidak membosankan, penuh motivasi, semangat, menarik perhatian dan sebagainya (Husamah, 2014).
Pemanfaatan teknologi pada sektor pendidikan tidak hanya digunakan pada ranah mengakses dan mencari informasi saja, melainkan juga sebagai sarana dan media dalam berinteraksi dalam proses pembelajaran yang dikenal saat ini dengan pembelajaran online. Dalam satu hari, setiap orang tidak bisa lepas dari gadget. Seseorang dapat menghabiskan berjam-jam untuk mengakses berbagai informasi secara online melalui 'makhluk kecil' bernama gadget. Beranjak dari hal tersebut, maka pembelajaran online merupakan sebuah keniscayaan yang harus diimplementasikan. Terlebih dalam belajar Alquran.

Kesadaran masyarakat dalam belajar dan menghafal Alquran sudah semakin tinggi. Hal ini ditandai dengan banyaknya orangtua yang menyekolahkan anaknya pada lembagalembaga pendidikan yang notabene include di dalamnya program menghafal Alquran. Namun, saat ini bukan hanya anak yang dianjurkan untuk menghafal Alquran, namun juga orangtuanya. Suatu hal yang dilematis, keterbatasan waktu yang dimiliki 
seseorang terkadang menghambat semangat dalam menghafal Alquran. Dengan perkembangan teknologi saat ini yang semakin canggih ditambah dengan fasilitas dan aplikasi di dalam gadget yang dimiliki seseorang, maka penghambat seseorang dalam belajar dan menghafal Alquran.

Secara historis, tradisi menghafal Alquran diawali dari para ulama yang pernah belajar di Timur Tengah. Para ulama tersebut di antaranya KH. Munawwir Krapuak, KH. Minawwar Gresik, dan KH. Said Ismail Sampang. Mereka melaksanakan kegiatan menghafal Alquran dengan metode talaqqi dan musyafahah. Dalam perkembangan berikutnya, tradisi ini semakin popular. Meskipun demikian, sampai tahun 1970, lembaga-lembaga tahfiz Alquran masih terbatas di beberapa daerah saja. Setelah munculnya event Musabaqah Tilawah Alquran (MTQ) pada tahun 1981, mulai bermunculan lembaga tahfiz di berbagai daerah di Indonesia (Sofyan, 2015).

Dewasa ini, sudah banyak bermunculan program-program yang digagas oleh para Ahli Quran yang ingin berkontribusi dalam pembelajaran Alquran. Salah satunya yaitu program 'tahfiz online'. Tahfiz online adalah program menghafal Alquran secara online menggunakan aplikasi whatsapp dan aplikasi tahfiz online.

Tahfiz online merupakan salah satu program bagi masyarakat yang ingin belajar dan menghafal Alquran secara online. Masyarakat yang ingin belajar dan menghafal Alquran dapat dijalankan melalui program ini.

Program tahfiz online merupakan program digagas oleh Ustadz Ikhsan Malik pada tahun 2016. Tahfiz online merupakan program terobosan dari Yayasan Indonesia Berkah yang mengubah paradigma masyarakat yang selama ini menganggap bahwa proses menghafal Alquran hanya dapat dilaksanakan secara tatap muka dengan guru dan dalam waktu yang bersamaan. Berbeda dengan proses menghafal Alquran pada umumnya, proses menghafal Alquran pada tahfiz online dapat dilaksanakan kapan dan dimanapun berada. Santri dan guru masing-masing mampu menyetorkan dan mengoreksi hafalan melalui media 
sosiial whatsapp (Wajdi, Fauzia, \& Hakam, 2020)

Founder Program ini, Ustadz Iksan menuturkn bahwa program terbentuk karena kepedulian terhadap dunia tahfidz Alquran. Beliau juga mencita-citakan agar semua orang turut mampu menikmati indahnya menghafal Alquran meskipun dalam kondisi keterbatasan waktu, biaya dan tempat. Ditambah lagi dengan terus berkembangnya dan familiar masyarakat dengan media sosial, menjadikan solusi bagi masyarakat untuk memanfaatkn gadget-nya untuk terus belajar dan menghafal Alquran (Malik, 2019).

\section{Pembelajaran tahfiz online} merupakan salah sarana bagi setiap orang untuk terus dekat dengan Alquran meskipun dalam kondisi sibuk atau tidak sempat untuk mondok di pesantren. Beragam rutinitas masyarakat khususnya di perkotaan yang menghabiskan waktu berjam-jam di kantor membuat seseorang memiliki berbagai dalih untuk tidak membaca Alquran dan menghafalkannya. Sementara Rasulullah telah mengingatkan bahwa "Sebaik-baik
Kamu adalah orang yang belajar Alquran dan Mengajarkannya'. Beranjak dari hadis tersebut, maka sudah selayaknya sesibuk apapun seseorang dengan beragam aktivitasnya untuk tetap belajar Alquran dan menghafalkannya.

Dalam menghafal Alquran, tiap orang menggunakan beberapa metode. Muthoifin dkk sebagaimana hasil penelitiannya terdapat beberapa metode dalam menghafal Alquran di antaranya juz’ $i, \operatorname{simā'i,~tasmī',~murāja'ah,~jama'.~}$ Metode $j u z$ ' $i$ yaitu menghafal Alquran dengan membagi ayat yang akan dihafal. Metode sima' $i$ yaitu menghafal dengan cara mendengarkan ayat yang akan dihafal. Metode tasmi' yaitu menghafalkan dengan mengikuti bacaan yang diulang-ulang oleh guru. Metode murajaah yaitu menghafal dengan mengulang-ulang ayat yang dihafal dengan cara membacanya ketika shalat, menuliskan ayat yang sudah dihafal dan mendengarkan bacaan Alquran dari salah satu qari/imam hafiz Alquran. Sedangkan metode jama' yatu menghafal Alquran dengan cara membaca dengan bersama- 
sama (Muthoifin, Anshori, \& Suryono, 2016).

Metode menghafal Alquran yang hampir senada dengan metode di atas yaitu metode tikrar atau takrar. Metode ini dilaksanakan dengan terus menerus mengulang ayat yang sudah dihafal. Hal ini dilakukan untuk menguatkan hafalan di dalam ingatan (Gade, 2014).

Menghafal Alquran memiliki begitu banyak manfaat. Sebagaimana dijelaskan Nurul Hidayah bahwa terdapat beberapa manfaat menghafal Alquran yaitu menjaga keaslian Alquran, meningkatkan kecerdasan berpikir, dan membentuk kepribadian yang mulia (Hidayah, 2016).

Penelitian ini tentunya berbeda dengan penelitian-penelitian yang terkait tahfiz Alquran. Pada umumnya, penelitian sebelumnya memfokuskan pada penelitian tahfiz di sekolah, madrasah, atau pesantren yang pelaksanaan pembelajaran tahfiz dilaksanakan secara tatap muka (talaqqi) dengan guru atau ustaz. Sedangkan pada penelitian ini memfokuskan pada pembelajaran tahfiz yang dilaksanakan non tatap muka dengan guru atau ustaz, namun dilaksanakan dengan pemanfaatan teknologi terutama dengan menggunakan gadget.

Pemanfaatan teknologi saat ini khususnya penggunaan gadget dalam menghafal Alquran sangat membantu seseorang untuk menghafal Alquran. Sebagaimana hasil penelitian Ihsan M. Arinal yang meneliti tentang aplikasi murajaah Alquran berbasis android bahwa aplikasi ini memiliki 2 menu utama dalam implementasinya, yaitu menu list penanda hafalan sebagai penanda batas hafalannya dan menu rekaman yang bisa memfasilitasi proses menghafal dan mengulang hafalan (murajaah) (Arinal, 2015).

Senada dengan penelitian di atas, Reza Pradana juga melakukan penelitian tentang aplikasi E-Hafiz yang dipergunakan untuk murajaah Alquran. Membaca Alquran secara rutin dan berulang-ulang akan memindahkan surat-surat yang telah dihafal dari otak kiri ke otak kanan (Sukoco \& Septiawan, 2015).

Secara umum metode menghafal Alquran dibagi menjadi tiga bagian. Metode pertama dinamakan metode keseluruhan dimana penghafal 
membaca satu halaman dari baris pertama hingga baris terakhir sampai hafal sempurna. Metode kedua disebut metode bagian dimana penghafal membaca ayat per ayat sampai hafal kemudian dilanjutkan membaca ayat berikutnya. Sedangkan metode ketiga merupakan gabungan dari metode pertama dan kedua, dimana penghafal terlebih dahulu menghafal satu halaman penuh kemudian mengulang-ulang menghafal beberapa bagian ayat untuk menguatkan hafalan (Hidayah, Afwani, \& Jatmika, Rancang Bangun Aplikasi Bantu Hafal Al-Qur'an Metode AtTaisir Berbasis Android, 2019).

Tujuan dari penelitian yaitu untuk mengetahui bagaimana implementasi kegiatan Tahfiz online mulai dari proses perekrutan santri, proses pembelajaran hingga proses evaluasi dalam pembelajaran.

\section{B. Metodologi Penelitian}

Metode penelitian yang digunakan yaitu metode kualitatif. Teknik pengumpulan data yang dilakukan yaitu dengan wawancara dan observasi. Penelitian ini dilakukan pada program menghafal
Alquran yang disebut tahfiz online. Fokus penelitian ini yaitu melihat bagaimana proses pembelajaran tahfiz Alquran yang dilaksanakan secara online tanpa bertatap muka yang dilaksanakan pada program tahfiz online.

Data-data yang dikumpulkan baik dari wawancara maupun observasi akan dianalisis dengan cara mengorganisasikan data. Semua data yang telah dikumpulkan dengan melalui berbagai teknik diatur, diurutkan, dikelompokkan dan dikategorikan sehingga dapat ditemukan hasilmya sesuai fokus penelitian ini.

\section{Pembahasan}

Tahfiz online merupakan sarana masyarakat untuk menghafal Alquran secara online. Begitu juga yang menjadi latar belakang munculnya program ini. Sebagaimana yang disampaikan oleh founder program ini--Ustaz Iksan--bahwa program ini merupakan sebagai jawaban dari kegelisahan masyarakat yang sangat ingin belajar dan menghafal Alquran, namun kondisi yang tidak 
memungkinkan

dikarenakan

keterbatasan waktu, tempat, biaya ditambah lagi yang dulunya tidak sempat untuk mondok di pesantren.

Program yang didirikan tahun 2016 ini sangat diminati oleh masyarakat. Hal ini dibuktikan dengan animo masyarakat yang ingin bergabung dengan program ini. Bahkan sebagaimana yang disampaikan Ustaz Iksan bahwa sampai saat ini tercatat santri yang ikut bergabung sudah mencapai 450 lebih dan jika diakumulasikan semua dari tiap periode sudah mencapai ribuan santri (Malik, 2019). Program ini terbuka untuk seluruh kalangan usia. Program ini diikuti oleh santri minimal berusia 12 tahun. Bahkan beberapa santri sudah mencapai usia 60 ke atas.

Prosedur pembelajaran menghafal Alquran di tahfiz online dilalui melalui beberapa proses. Pertama, tiap santri yang ingin bergabung pada program ini, diharuskan untuk registrasi atau pendaftaran. Setelah registrasi, dilaksnakan proses rekrutmen atau seleksi calon santri yang dilanjutkan pada pengumuman hasil penerima calon santri. Kedua, proses pembelajaran. Setelah dinyatakan lulus, tiap santri diberikan kesemptan untuk mengikuti proses pembelajaran pada program tahfiz online. Ketiga, setelah proses pembelajaran telah dilaksnakan, maka santri akan melalui tahapam terakhir yaitu evaluasi atau dikenal pada program ini dengan imtihan.

\section{Proses Rekrutmen Santri}

Berdasar dari hasil wawancara dengan founder tahfiz online yaitu Ustaz Iksan, proses rekrutmen santri baru dilakukan dengan melakukan tes. Tes yang diujikan yaitu tes membaca Alquran. Prosedur tes seleksi calon santri ini dilalui dengan tiap santri mengirimkan pesan suara (voice note) melalui media whatsapp kepada guru atau musyrif. Selanjutnya, pesan suara (voice note) disimak dan diberi penilaian kebenaran bacaannya baik dari sisi makhraj maupun tajwidnya oleh ustaz atau musyrif yang bertugas. Hasil dari penilaian tes ini menjadi dasar pertimbangan pihak tahfiz online dalam menentukan keputusan 
diterima atau tidak calon santri yang mendaftar.

Selanjutnya, santri yang dinilai layak untuk masuk dalam program tahfiz online, akan dikumpulkan dalam sebuah grup whatsapp dengan nama grup calon santri. Pada tahapan ini, setiap calon santri akan dijelaskan prosedur dan tahapan-tahapan pembelajaran serta adab dalam mengikuti tahfiz online. Pada tahapan ini juga setiap santri diberi buku pedoman tahfiz online. Calon santri diberi waktu untuk membaca dan mempelajari pedoman tersebut dengan baik. Berikutnya, di dalam grup whatsappp tersebut setiap calon santri diberikan kesempatan untuk mengajukan pertanyaan seputar tahfiz online dan program-programnya.

Tahapan berikutnya, calon santri dikumpulkan dalam grup yang disebut Halaqah Besar dan Halaqah Kecil. Halaqah Besar atau yang diisingkat HB ini merupakan grup tempat dimana setiap santri saling berkenalan dan bersilaturrahim. Selain itu, HB juga merupakan wadah untuk motivasi harian, motivasi Alquran, kajian Alquran, dan ruang imtihan baik setengah atau satu juz.

Selain itu, grup HB ini juga merupakan wadah untuk saling berbagi ilmu antarsesama santri atau antara ustaz atau musyrif dengan santri. Sedangkan, Halaqah Kecil atau yang disingkat HK merupakan grup kecil tempat santri untuk menyetorkan hafalannya dan mendapatkan penilaian atau evaluasi dari setiap bacaan Alquran yang telah dihafalkan.

Peserta yang mengikuti tahfiz online berasal dari berbagai daerah di Indonesia. Berdasar dari hasil penelitian, didapatkan data bahwa santri yang mengikuti tahfiz online ini berasal dari pulau Sumatera, Jawa, Kalimantan Papua, Bahkan terdapat beberapa santri dari Indonesia yang berdomisili di luar negeri di antaranya di Polandia dan Swiss.

\section{Proses Pembelajaran Tahfiz}

$$
\text { Pembelajaran menghafal }
$$

Alquran pada program ini, tidak jauh berbeda dengan kegiatan tahfiz lainnya. Di antaranya ada kegiatan menambah hafalan (ziyadah) dan mengulang hafalan (murajaah). Pada 
umumnya proses menghafal dan menyetorkan hafalan dilakukan secara talaqqi dengan guru. Sebagaimana hasil penelitian dari Rusadi bahwa dalam pelaksanaan menghafal Alquran yang dilakukan oleh santri Nurul Quran dilakukan dengan talaqqi dan takrir (Rusadi, 2018). Pada kegiatan pembelajaran tahfiz. online dilakukan secara online tanpa bertatap muka dengan guru. Berdasarkan hasil wawancara dan observasi didapatkan data bahwa proses setoran hafalan baru (ziyadah) dilaksanakan setiap hari Senin sampai Jumat melalui aplikasi whatsapp. Kegiatan menghafal Alquran dilaksanakan oleh setiap santri secara mandiri. Setiap santri hanya menyetorkan hafalannya di dalam grup whatsapp. Setiap santri diberikan kesempatan untuk menyetorkan hafalannnya di dalam grup yang disebut Halaqah Kecil atau disingkat HK. Dalam grup ini terdapat 6 sampai 8 santri yang dibimbing oleh satu musyrif atau musyrifah. Setiap santri diberi kesempatan untuk menyetorkan hafalannya di grup tersebut dimulai dari pukul 03.00 sampai 21.00 WIB.
Jumlah hafalan yang disetorkan setiap hari minimal 1 ayat dan maksimal 1 halaman.

Namun, ada yang menarik pada tahfiz online ini yang menjadi distingsi pada program pembelajaran Alquran secara online lainnya bahwa waktu penyetoran menjadi bagian dari penilai tahfiz online ini. Pada pukul 03.00 tepat, santri yang menyetorkan hafalannya disebut mengikuti Lintasan Awal atau yang sering disebut $L A$. Kegiatan setor hafalan diawali dengan membuat format hafalan. Santri yang membuat format hafalan tepat pukul 03.00 dan kemudian menyetorkan hafalan maka dikategorikan masuk dalam Lintasan Awal. Format hafalan dalam tahfiz ini juga unik yaitu J30 H582 B1-15 03.00. Format hafalan tersebut bermakna bahwa santri tersebut menyetorkan hafalan juz 30 (J30), halaman 582 (H582), baris ke 1 sampai 15 (B1-15), dan 03.00 menunjukkan waktu setoran hafalannya. Format yang dibuat bertujuan agar setiap santri tidak sekadar menghafal ayatnya saja namun juga menghafal juz, halaman, 
baris dari setiap ayat yang telah dihafalnya.

Santri yang masuk dalam kategori $L A$ maka akan mendapatkan nilai 100. Sementara itu, santri yang menyetorkan hafalan dari pukul 03.01 sampai 03.59 mendapatkan nilai waktu 90. Santri yang menyetorkan hafalan pukul 04.00-04.59 mendapatkan nilai 80 dan dari 05.00 sampai 05.59 mendapatkan nilai 70 . Sedangkan dari pukul 06.00 hingga pukul 21.00 santri hanya mendapatkan nilai 50. Penilaian Lintasan Awal ini tidak hanya sekadar memberikan semangat bagi setiap santri untuk mendapatkan nilai waktu yang terbaik ketika menyetorkan hafalannya, namun juga membiasakan setiap santri untuk bangun malam untuk melaksanakan qiyamul lail. Kegiatan ini sejalan dengan firman Allah yang menjelaskan bahwa waktu tahajjud merupakan terbaik untuk membaca Alquran.

Hafalan yang sudah disetorkan oleh setiap santri akan dikoreksi kebenarannya baik dari sisi hafalan maupun kebenaran tajwid dan makhraj hurufnya oleh setiap musyrif pada masing-masing $H K$. Setiap hari, setiap musyrif akan memberikan penilaiannya terhadap hafalannya yang sudah dihafalkan setiap santri. Penilaian yang diberikan juga disampaikan melalui grup baik berupa catatan maupun pesan suara (voice note).

Sementara itu, kegiatan murajaah dilaksanakan setiap hari Sabtu dan Minggu. Kegiatan murajaah dilaksanakan dengan berpasangan. Setiap musyrif akan membagi santri berpasangan. Proses murajaah ini dilaksanakan dengan diawali membuat format seperti format hafalan biasa dengan ditambah huruf M (Murajaah) di depannya yaitu $M J 30$ H582 B1-15 03.00. Setiap santri mengirimkan format hafalannya di grup $H K$, sementara murajaah hafalannya disetorkan dengan pasangan yang sudah ditentukan.

Kegiatan pembelajaran tahfiz online ini tidak hanya sebatas ziyadah dan murajaah saja, namun setiap hari Sabtu atau Minggu, santri diajak untuk belajar sambil bermain dengan adanya kuis. Konten kuis yang diberikan seputar ilmu tajwid dan 
pengetahuan agama laiinnya. Hal ini memberikan semangat kepada setiap santri untuk berkompetisi. Bahkan dari setiap kuis ini, santri yang berhasil menjawab paling banyak, akan mendapatkan poin penilaian.

Beranjak dari penjelasan maka dapat disimpulkan bahwa proses menghafal Alquran di dalam tahfiz online dilaksanakan dengan mengirimkan pesan suara (voice note) di dalam grup whatsapp. Pada tahapan ini, meskipun santri tidak bertatap muka dengan musyrif atau guru penanggungjawab tahfiz tersebut, namun setiap santri seolah-olah berhadapan dengan gurunya secara langsung. Pada tahapan menyetorkan hafalan juga santri dibiasakan untuk bersikap jujur yaitu dengan menyetorkan hafalannya tanpa melihat mushaf Alquran. Selanjutnya, pada kegiatan menghafal juga santri dibekali dengan kemampun untuk mengingat juz, halaman, serta baris ayat yang sudah dihafal dengan membuat format hafalan.

Sementara pada kegiatan murajaah, santri dibiasakan untuk bersikap bertanggungjawab dan mampu untuk menjadi guru atau tutor untuk teman murajaah-nya dengan saling mengoreksi murajaah hafalan pasangannya. Beranjak dari hal ini, maka kegiatan murajaah memang merupakan sebuah keniscayaan di dalam kegiatan pembelajaran tahfiz Alquran.

Kegiatan mengulang hafalan atau dikenal dengan murajaah merupakan yang amat urgen bagi setiap penghafal Alquran. Proses menghafal tidak sulit, namun konsisten untuk mengulang hafalan merupakan kegiatan yang membutuhkan kesungguhan dan konsistensi bagi setiap para penghafal Alquran. Pembacaan ayat Alquran yang dilakukan berulang-ulang akan menguatkan hafalan bagi setiap penghafal Alquran.

\section{Proses Evaluasi}

Kegiatan pembelajaran tahfiz Alquran tidak lengkap tanpa adanya proses penilaian atau evaluasi. Begitu juga pada pembelajaran tahfiz di tahfiz online. Proses pembelajaran tahfiz di tahfiz online berlangsung selama 4 pekan setiap gelombangnya. 
Kegiatan tahfiz secara rutin dilaksanakan Senin sampai Jumat dengan kegiatan ziyadah (menambah hafalan Alquran) dan Sabtu sampai Minggu dengan kegiatan murajaah (mengulang hafalan Alquran). Setelah terlalui proses tersebut, maka santri berhak untuk mengikuti proses penilaian atau evaluasi pembelajaran tahfiz yang dilaksanakan pada program tahfiz online. Evaluasi pembelajaran tahfiz pada tahfiz online dilaksakan tiap pekan. Adapun aspek penilaian tiap pekannya yaitu nilai setoran harian, keaktifan dan adab. Ketiga aspek tersebut diakumulasikan dan dirata-ratakan dan hasilnya diinformasikan kepada tiap santri melalui aplikasi instagram tahfiz online.

Evaluasi yang dilaksanakan pada tahfiz online terbagi atas dua istilah, yaitu Imtihan Nishfu dan IMTAK. Imtihan Nishfu yaitu evalusi yang dilaksanakan untuk menguji kemampuang menghafal Alquran bagi santri yang hafalannya telah mencapai pertengahan juz. Setiap santri yang hafalannya telah mencapai pertengahan juz maka diperkenankan untuk mengikuti Imtihan Nishfu (ujian setengah juz). Pelaksanaan ujian akan dilaksanakan secara online di dalam grup HB (Halaqah Besar). Sementara pertanyaan yang diberikan yaitu 3 soal untuk tiap santri. Teknis pelaksanaan evaluasi dilaksanakan dengan seorang musyrif memberikan satu pertanyaan kepada santri melalui pesan suara (voice note), kemudian santri menjawab dan dilanjut pada soal berikutnya hingga soal ketiga.

Sementara IMTAK merupakan singkatan dari Imtihan Akbar. Pada tahapan evaluasi ini, setiap santri akan diklasifikasikan sesuai dengan ketercapaian dengan hafalan yang sudah disetorkan setiap hari. Santri yang telah mencapai setengah juz maka musyrif akan memasukkan santri tersebut pada grup whatsapp ujian setengah juz. Begitu juga pada santri yang telah mencapai satu juz, musyrif juga akan mengklasifikasikan dan memasukkan santri tersebut ke dalam grup whatsapp ujian satu juz. Pertanyaan yang diberikan pada IMTAK ini, tidak terdiri dari dua bagian, yaitu ujian teori dan ujian hafalan. Pada ujian teori, santri 

dalam bentuk google form yang diberikan kepada setiap santri melalui grup ujian masing-masing. Selanjutnya, setiap santri diberikan 3 soal hafalan yang dikirimkan melalui grup whatsapp dalam bentuk pesan suara (voice note). Ujian teori dijawab oleh santri melalui google form, sementara ujian hafalan dikirimkan ke nomor musyrif yang bertanggungjawab pada ujian tersebut. Indikator kelulusan santri pada tahfiz online tidak terbatas pada IMTAK saja, namun terdapat aspek penilaian lain yang mendukung kelulusan santri pada tahfiz online ini. Aspek penilaian lain yang menjadi indikator penilaian yaitu nilai setoran harian, keaktifan dan adab. Nilai setoran harian diakumulasikan dari nilai yang diberikan musyrif dari setoran harian santri. Nilai keaktifan diambil dari aktif atau tidaknya setiap santri untuk merespon atau mengirimkan informasi yang bermanfaat pada grup Halaqah Besar (HB). Sedangkan nilai adab adalah nilai adab tiap santri yang diberikan oleh setiap musyrif pada tiap grup diberikan 10 soal multiple choice

Halaqah Kecil (HK) yang dinilai dari keaktifan santri untuk merespon dari setiap informasi yang diberikan oleh musyrif atau dari hasil penilaian yang telah diberikan oleh musyrif.

Keseluruhan indikator penilaian tersebut diakumulasikan dan dirataratakan oleh musyrif yang bertanggungjawab untuk merekap nilai. Setelah semua nilai santri diakumulasikan maka hasil ujian tahfiz online akan dikirimkan di instagram tahfiz online untuk dapat dilihat oleh seluruh santri.

\section{Simpulan}

Penggunaan gadget yang saat ini terus menjamur harus dimanfaatkan untuk kebaikan, salah satunya untuk menghafal Alquran.

$\begin{array}{lcr}\begin{array}{l}\text { Menghafal } \\ \text { dilaksanakan }\end{array} & \text { kapanpun } & \text { dan } \\ \text { dimanapun } & \text { hanya } & \text { cukup } \\ \text { menggunakan } & \text { aplikasi } & \text { whatsapp. } \\ \text { Program tahfiz } & \text { online } & \text { merupakan } \\ \text { wadah bagi } & \text { masyarakat } & \text { untuk } \\ \text { menyalurkan } & \text { semangat } & \text { dalam } \\ \text { menghafal Alquran meskipun dalam } & \\ \text { kondisi sibuk dan tidak } & \text { memiliki } \\ \text { waktu untuk } & \text { bertemu langsung }\end{array}$


dengan guru. Pembelajaran tahfiz Alquran yang ditawarkan program tahfiz online tidak kalah menarik dengan pembelajaran tahfiz pada umumnya. Diawali proses rekrutmen yang menantang, kemudian dilanjutkan proses menghafal dan penilaian yang menarik pada program ini, menjadikan magnet buat masyarakat untuk mengikuti program ini. Animo masyarakat yang begitu tinggi pada program ini memberikan sinyal bahwa semangat masyarakat untuk menghafal masih cukup tinggi. Hal ini, juga menjadi tradisi yang sangat baik bagi masyarakat untuk menjaga kemurnian Alquran dengan cara menghafalkannya.

\section{E. Daftar Pustaka}

Arinal, I. M. (2015). Aplikasi Muroja'ah Al-Qur'an Sebagai Media Untuk Membantu Menghafal Juz Amma Berbasis Android. Tesis: Universitas Muhammadiyah Malang, 1.

Gade, F. (2014). Implementasi Metode Takrar Dalam Pembelajaran Menghafal Alquran. Jurnal
Ilmiah Didaktika, 14(2), 413425.

Hidayah, N. (2016). Strategi Pembelajaran Tahfidz AlQur'an Di Lembaga Pendidikan. Ta'allum: Jurnal Pendidikan Islam, 4(1), 63-81.

Hidayah, N., Afwani, R., \& Jatmika, A. H. (2019). Rancang Bangun Aplikasi Bantu Hafal Al-Qur'an

Metode At-Taisir Berbasis Android. Journal of Computer Science and Informatics Engineering (J-Cosine), 3(1), 30-38.

Husamah. (2014). Pembelajaran Bauran (Blended Learning). Jakarta: Prestasi Pustaka.

Malik, I. (2019, Juni 28). Pemanfaatan Gadget dalam Menghafat Alquran. (B. E. Rusadi, Interviewer)

Muthoifin, M., Anshori, A., \& Suryono, S. (2016). Metode Pembelajaran Tahfiz Al-Quran Di Madrasah Aliyah Tahfiz Nurul Iman Karanganar Dan Madrasah Aliyah Al-Kahfi 
Surakarta. Profetika, Jurnal

Studi Islam, 17(2), 32-33.

Rusadi, B. E. (2018). Implementasi Pembelajaran Tahfiz Al-Quran Mahasantri Pondok Pesantren Nurul Quran Tangerang Selatan. Intiqad: Jurnal Agama dan Pendidikan Islam, 11(1), 268.

Sofyan, M. (2015). The Development of Tahfiz Qur'an Movement In The Reform Era In Indonesia. International Journal of Religious Literature and Heritage, 4(1), 118.

Sukoco, \& Septiawan, R. P. (2015). Pembangunan Aplikasi E-Hafis Sebagai Media Untuk Menghafal Al-Quran Berbasis

Android. Tesis: Universitas Muhammadiyah Malang,, 1.

Wajdi, F., Fauzia, S., \& Hakam, A. (2020). Evaluasi Program Tahfidz Melalui Media Sosial di Yayasan Indonesia Berkah. Jurnal Online Studi Alquran, 16(1), 69-88. 